\title{
Apis florea and Apis cerana workers do not discriminate between queen-laid and worker-laid Apis mellifera eggs
}

\author{
Piyamas N. SopaladaWAN $^{1}$, Benjamin P. OldRoYd ${ }^{2}$, Siriwat WONGSIRI $^{3}$ \\ ${ }^{1}$ Department of Biology, Faculty of Science, Mahasarakham University, Khamriang, Kantarawichai, Maha Sarakham \\ 44150, Thailand \\ ${ }^{2}$ Behaviour and Genetics of Social Insects Laboratory, Ecology and Evolution, University of Sydney, Macleay Building \\ A12, Sydney, NSW 2006, Australia \\ ${ }^{3}$ The Academy of Science, The Royal Society of Thailand, Dusit, Bangkok 10330, Thailand
}

Received 14 November 2018 - Revised 17 May 2019 - Accepted 15 July 2019

\begin{abstract}
While honey bee workers have functional ovaries, worker reproduction is rare in colonies with a laying queen. An important mechanism by which functional worker sterility is enforced is worker policing - any behaviour of workers that prevents other workers from reproducing. In honey bees, policing workers identify worker-laid eggs and eat them. Policing workers apparently distinguish queen-laid eggs from eggs laid by workers using as yet unidentified chemical signals placed on eggs. These signals are conserved across evolutionary time because the Western hive bee Apis mellifera can distinguish queen- and worker-laid eggs of the phylogenetically distant dwarf honey bee Apis florea. However A . mellifera cannot distinguish queen- and worker-laid eggs of the more closely related species Apis cerana. Here we show that $A$. cerana and $A$. florea workers do not distinguish queen-laid from worker-laid eggs of $A$. mellifera, even though A . cerana (but not $A$. florea) tolerate $A$. mellifera eggs for extended periods.
\end{abstract}

\section{Apis florea / Apis cerana / Apis mellifera / worker policing / egg-marking signals}

\section{INTRODUCTION}

In eusocial hymenopterans, the males are haploid and arise from unfertilized eggs, whereas females (queens and workers) are diploid and arise from fertilized eggs (Dzierzon 1845; Crozier and Pamilo 1996). This means that in many species, unmated workers can lay eggs that result in viable males (Bourke 1988). However, in most species, workers with a queen rarely lay eggs and reproduction is monopolized by mated queens. For example, in honey bee (Apis) colonies, the vast majority of honey bee workers have

Corresponding author: P. Sopaladawan, piyamas.n@msu.ac.th

Manuscript editor: David Tarpy thread-like ovaries in which egg production is absent (Halling et al. 2001; Oldroyd et al. 2001a, b; Wattanachaiyingcharoen et al. 2002). In queenright colonies of the Western honey bee, A. mellifera, only one worker in 10,000 has a fully developed egg in her ovary (Ratnieks 1993), and workers produce less than $7 \%$ of the maledestined eggs (Visscher 1996). Almost all workerlaid eggs are promptly removed by worker policing (Ratnieks and Visscher 1989; Ratnieks 1993).

'Worker policing' is any behaviour of workers that prevents other workers from producing sons, either by aggression toward reproductive workers or by the destruction of worker-laid eggs (Ratnieks 1988; Ratnieks and Visscher 1989; Ratnieks and Reeve 1992; Barron et al. 2001; Ratnieks and Wenseleers 2005). Worker policing likely evolves via two processes. First, in 
polyandrous species, where workers are more related to their queen's sons $(r=0.25)$ than to the sons of their half-sisters $(r=0.125)$, workers are selected to prefer to rear their queen's sons rather than their half-sister's sons (Hamilton 1964; Ratnieks 1988). Second, colony efficiency can be compromised if a large proportion of workers are reproductive (Montague and Oldroyd 1998). In species where policing is highly effective, the benefits of egg laying are much diminished for workers, and they are likely to evolve reproductive 'acquiescence'. Where acquiescence has evolved, workers with a queen rarely (and in some species never) produce eggs (Wenseleers et al. 2004a, b; Wenseleers and Ratnieks 2006).

Even though worker acquiescence (sterility) may have evolved because it benefits the collective workers, individual workers are still more related to their own eggs than to queen-laid (hereafter QL) or worker-laid (hereafter WL) eggs (Ratnieks 1988). Therefore, there is an evolutionary tension between the optimal behaviour for the individual and the optimal behaviour of the collective workers (Wenseleers et al. 2004a, b; Ratnieks et al. 2006). Indeed, even in a species like $A$. mellifera where worker acquiescence is almost complete, some workers successfully produce offspring during swarming periods (Woyciechowski and Kuszewska 2012; Holmes et al. 2013; Kuszewska et al. 2018). It is also possible to artificially select for high levels of worker reproduction (Oldroyd and Osborne 1999) and low levels of policing (Oldroyd et al. 2001a, b).

The underlying genetic and phenotypic plasticity in worker sterility means that workers can potentially evolve resistance to policing, leading to 'episodes of worker revolution' (Wenseleers et al. 2004a, b). During these episodes, a species endures a period when the efficiency of policing declines, workers contribute a significant proportion of the male offspring of a colony, and the species suffers the ergonomic costs of increased intra-colony conflict and reduced ergonomic efficiency.

Police workers discriminate queen-laid (QL) eggs from worker-laid (WL) eggs using unidentified signals present on eggs (Katzav-Gozansky et al. 1997; 2001; Barron et al. 2001; Martin et al. 2002, 2005). This signal is most likely a queen-derived pheromone placed on eggs
(Ratnieks 1995; Oldroyd et al. 2002; Beekman et al. 2004). The queen's egg-marking signal benefits both the queen (sender) and police workers (receiver) (Seeley 1985; Heinz and d'Ettorre 2009). The signal benefits the queen because it reinforces her reproductive hegemony. Police workers benefit because the signal allows them to raise more-related QL eggs and fewer, lessrelated, WL eggs.

A clear prediction of inter-animal signaling theory is that if signals are honest and benefit both sender and receiver, then the signal should be stable over evolutionary time (Hefetz and Katzav-Gozansky 2004; Nanork et al. 2007b; Jäger 2008). In contrast, if a signal benefits only one party, or if a party can benefit by mimicking the signal, the signal may change over evolutionary time as the receiver changes its response to the signal to its own advantage, possibly by ignoring it (Hefetz and Katzav-Gozansky 2004; Jäger 2008). In this circumstance, the sender may alter its signal, so that it can be recognized as genuine.

We have previously shown that colonies of $A$. mellifera can distinguish QL from WL eggs of the red dwarf honey bee, Apis florea, but cannot distinguish between QL and WL eggs of the Asian hive bee, Apis cerana (Nanork et al. 2007b). A . mellifera and A cerana diverged less than 3 mya (Arias and Sheppard 2005), whereas the divergence of $A$. florea from the $A$. mellifera $-A$. cerana clade is much more ancient (Arias and Sheppard 2005; Raffiudin and Crozier 2007; Lo et al. 2010), about 6-10 mya (Engel 1998; Engel 1999). This suggests that an 'episode of revolution' (Wenseleers et al. 2004a, b) has occurred in A. cerana (Nanork et al. 2007b) in which, $A$. cerana workers evolved to mimic the queen's egg-marking signal, forcing a change in the queen egg-marking signal. That means that whereas the queen's egg-marking signal is similar in $A$. mellifera and $A$. florea, it has diverged between A. mellifera and A. cerana, despite their more recent co-ancestry.

Here we present the reverse experiment of Nanork et al. (2007b) to investigate the relative abilities of $A$. florea and $A$. cerana to discriminate QL and WL eggs of $A$. mellifera. We predicted that $A$. florea would retain some ability to distinguish QL and WL eggs of $A$. mellifera, 
whereas $A$. cerana would be less able or unable to distinguish QL and WL eggs of $A$. mellifera. Note that both $A$. florea (Halling et al. 2001) and A . cerana (Oldroyd et al. 2001a) police WL eggs of their own species, while retaining QL eggs.

\section{MATERIALS AND METHODS}

\subsection{Sources of eggs}

Four colonies of $A$. mellifera were transferred to a coconut plantation in Damnoen Saduak, Ratchaburi Province, Thailand. The colonies were left at the field for a month. One colony lost its queen while the colonies were being moved, and we used this colony as a source of worker-laid (WL) eggs which we harvested from worker cells. In the queenright colonies, we confirmed the presence of the queen before collecting QL eggs from worker cells. We used fertilized (female) QL eggs from worker cells because insufficient male QL eggs were present in drone cells. We have previously shown that the survival of female and male QL eggs in policing assays is similar in both $A$. mellifera (Oldroyd and Ratnieks 2000) and $A$. florea (Nanork et al. 2007b).

\subsection{Discriminator colonies}

A. florea Six colonies of A. florea were wildcaught from Samut Songkhram Province and transported, as described in Halling et al. (2001) and Nanork et al. (2005, 2006, 2011), to the coconut plantation in Ratchaburi. We attached our discriminator colonies to tree branches approximately $1.5-2 \mathrm{~m}$ from the ground, and verified that they each had a queen. The colonies were positioned at least $5 \mathrm{~m}$ apart and were left to settle down for a week. Two colonies absconded during this period, leaving four for use as discriminator colonies.

In $A$. florea, the drone comb is built beneath the main comb (Oldroyd and Wongsiri 2006). We removed the drone comb sections from four colonies, and kept them frozen overnight at $-20{ }^{\circ} \mathrm{C}$ to kill eggs and larvae. We then affixed a loop of light wire to each drone comb so that it could be suspended beneath a discriminator colony. A test drone comb was suspended underneath each colony in the position of natural drone comb. Before the experiment, we hung each test comb next to a queenright discriminator colony so that the bees cleaned and polished it.

A. cerana Four colonies were wild-caught from Samut Songkhram, transferred to artificial boxes, and left to establish their nests at the natal site for 2 weeks (Nanork et al. 2007a, b). We transported the four queenright $A$. cerana colonies to the coconut plantation in Ratchaburi and left them there for a week prior to performing experiment. Drone combs of $A$. cerana were obtained from absconded colonies which had been kept at Mahasarakham University. The drone combs were stored at $-20{ }^{\circ} \mathrm{C}$ for a month. Before use, test combs were placed in a queenright colony overnight so that the bees cleaned the combs and repaired any damaged cells.

\subsection{Policing assays}

Assays were conducted when environmental conditions were good for honey bees with respect to adequate supplies of nectar and pollen. Standard policing bioassays (Ratnieks and Visscher 1989; Oldroyd and Ratnieks 2000) were performed using four A. cerana and four A. florea discriminator colonies. The $A$. cerana discriminator colonies comprised 5-6 frames of bees and brood.

To perform an assay, three rows of drone cells were identified in the test drone comb and permanently identified by inserting colored drafting pins into the comb at the beginning of each of the three rows. Twenty QL eggs were placed in one row and $20 \mathrm{WL}$ eggs in one row using modified forceps (Taber 1961; Ratnieks and Visscher 1989). One row was left blank to check if any oviposition occurred during the assay.

\subsubsection{A. florea discriminator colonies}

Four queenright $A$. florea discriminator colonies were used to determine the removal rates of A. mellifera eggs from different sources. Six trials were conducted in each of three discriminator 
colonies and four trials in another colony. We transferred a total of $440 \mathrm{QL}$ and $440 \mathrm{WL} A$. mellifera eggs to discriminator colonies. Assays were conducted over a period of 4 days. We inspected the test combs after 10, 20, 30, and $40 \mathrm{~min}$, recorded the number of remaining WL and QL eggs, and checked for the presence of any eggs in the control row.

\subsubsection{A. cerana discriminator colonies}

We used four queenright discriminator colonies of $A$. cerana for the assays. A total of $440 \mathrm{QL}$ and $440 \mathrm{WL}$ A. mellifera eggs were transferred to discriminator colonies. Egg survival was then examined after 10, 20, 30, 40, $50 \mathrm{~min}, 1$, 1.5, 2, 3, 4, 5 , and $6 \mathrm{~h}$. Five trials were conducted in each of two colonies, four trials in one colony, and eight trials in another colony. Each assay was conducted over a period of 8 days.

\subsection{Statistical analyses}

Cox regression survival analysis (Collett 1994) was performed as implemented in SPSS. Eggs of A. mellifera laid by queens and laying workers were compared using exact failure (i.e., a transferred egg was removed at 10, 20, 30, and $40 \mathrm{~min}$ for A florea discriminator colonies and at 10, 20, $30,40,50,60,90,120,180,240,300$, and $360 \mathrm{~min}$ for $A$. cerana discriminator colonies). The null hypothesis in a Cox regression model assumes that the hazard rate (i.e., probability of egg removal) at any given time for an individual egg in one group is proportional to the hazard at that time for a similar egg in the other group. We constructed the model using the following variables: egg source (QL or WL), trial, and discriminator colony. The mean proportion of surviving eggs at each time is presented.

\section{RESULTS}

\subsection{A. mellifera eggs in A. florea discriminator colonies}

Both QL and WL eggs of $A$. mellifera were completely removed by $A$. florea workers within $40 \mathrm{~min}$. There was no significant difference in survival among eggs of different sources (Table I, Figure 1). Discriminator colonies did not differ significantly in their treatment of eggs (Table I) and all discriminators removed both types of eggs at an equal rate.

\subsection{A. mellifera eggs in A. cerana discriminator colonies}

A . cerana workers removed A. mellifera eggs at a much slower rate than $\operatorname{did} A$. florea workers, with some eggs remaining $6 \mathrm{~h}$ after transfer. Cox regression analysis shows no significant difference in survival of QL and WL A . mellifera eggs in A cerana discriminator colonies (Table I, Figure 2). Discriminator colonies differed significantly in their treatment of eggs (Table I), but all discriminators removed QL and WL eggs at the same rate (Table I).

\section{DISCUSSION}

Worker policing assays in A. florea (Halling et al. 2001) and A . cerana (Oldroyd et al. 2001a) show that workers of both species retain QL and WL eggs of their own species for more than $4 \mathrm{~h}$ and remove WL eggs significantly faster than QL eggs. This indicated that workers of both species can recognize whether a con-specific egg is queen- or worker-laid by signals placed on it.

This current study shows that $A$. florea colonies remove $A$. mellifera eggs within an hour, presumably because the eggs are recognized as being foreign or diseased. Because the rate of removal is so rapid, it is impossible to say whether A. florea workers can discriminate between WL eggs and QL eggs, but we have no evidence that they can. On the other hand, A. cerana retains both QL and WL A . mellifera eggs approximately 9 times longer than $A$. florea, presumably because the evolutionary divergence of $A$. cerana and $A$. mellifera is less than that of $A$. florea and A. mellifera (Figure 3, Oldroyd and Wongsiri 2006). Because $A$. cerana tolerates $A$. mellifera eggs for an extended period, there should have been plenty of time for $A$. cerana police workers to recognize and remove WL $A$. mellifera eggs if they are able to recognize WL eggs. Clearly they cannot. 
Table I. Likelihood ratios comparing the survival of $A$. mellifera eggs of different sources (QL and WL; $n=440$ for each egg source) in A . florea discriminator colonies and A cerana discriminator colonies. The survival function is modeled without ('Null') and with egg source, trial, and discriminator colony ('Overall') as factors. The procedure then tests the effect of adding 'Source of eggs', 'Trial', or 'Discriminator'. Eggs of A. mellifera were obtained from a queenless colony and 3 queenright colonies.

\begin{tabular}{llllll}
\hline Discriminator colony (Species) & Term & $-2 \log$ likelihood & $\chi^{2}$ & df & $P$ \\
\hline A.florea & Null & $11,450.84$ & & & \\
& Overall & $11,443.80$ & 6.80 & 9 & 0.657 \\
& Source of eggs (QL or WL) & & 0.04 & 1 & 0.836 \\
& Discriminator & & 4.86 & 3 & 0.182 \\
& Trial & & 2.63 & 5 & 0.757 \\
A.cerana & Null & 9255.09 & & & \\
& Overall & 9080.86 & 173.04 & 11 & $<0.001$ \\
& Source of eggs (QL or WL) & & 0.71 & 1 & 0.40 \\
& Discriminator & & 156.96 & 3 & $<0.001$ \\
& Trial & 61.65 & 7 & $<0.001$ \\
\hline
\end{tabular}

This study provides further support for the hypothesis that the A cerana egg-marking pheromone has undergone a period of rapid evolution (Nanork et al. 2007b) as a consequence of an 'episode of worker revolution' sensu Wenseleers et al. (2004a, b) (Figure 3). Although A . cerana tolerates some $A$. mellifera eggs for more than $6 \mathrm{~h}$, it does not selectively remove WL eggs. This

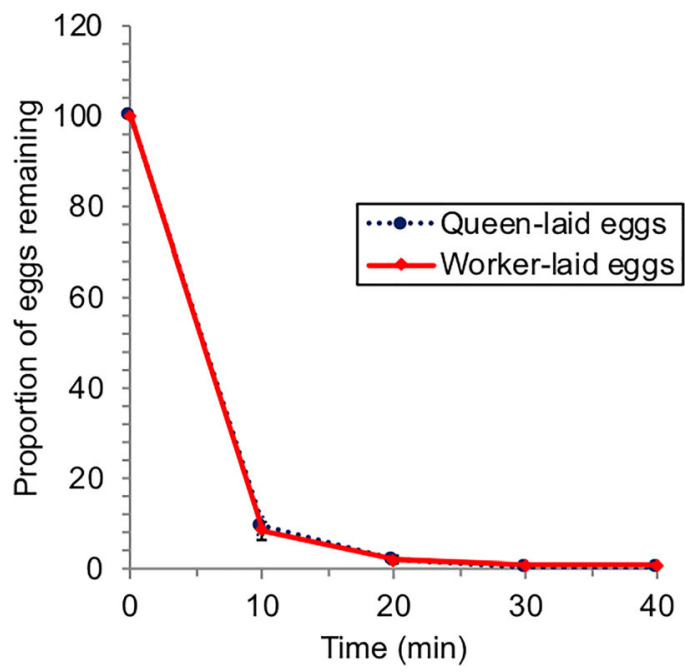

Figure 1. Survival of worker-laid (WL) and queen-laid (QL) eggs of $A$. mellifera in queenright $A$. florea discriminator colonies. Error bars indicate standard errors (SEs) of the means. suggests that $A$. cerana does not recognize the $A$. mellifera queen egg-marking signal because the A . cerana egg-marking signal has diverged from an ancestral signal that has been retained by both A. florea and A. mellifera (Nanork et al. 2007b). Whether $A$. cerana police workers regard all $A$. mellifera eggs (both QL and WL) as being WL or QL is unclear.

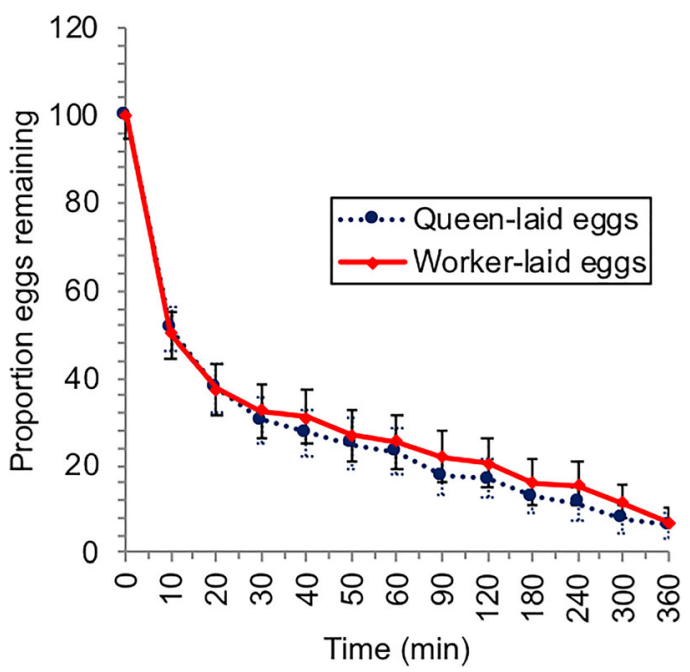

Figure 2. Survival of worker-laid (WL) and queen-laid (QL) eggs of $A$. mellifera in queenright $A$. cerana discriminator colonies. Error bars indicate standard errors (SEs) of the means. 

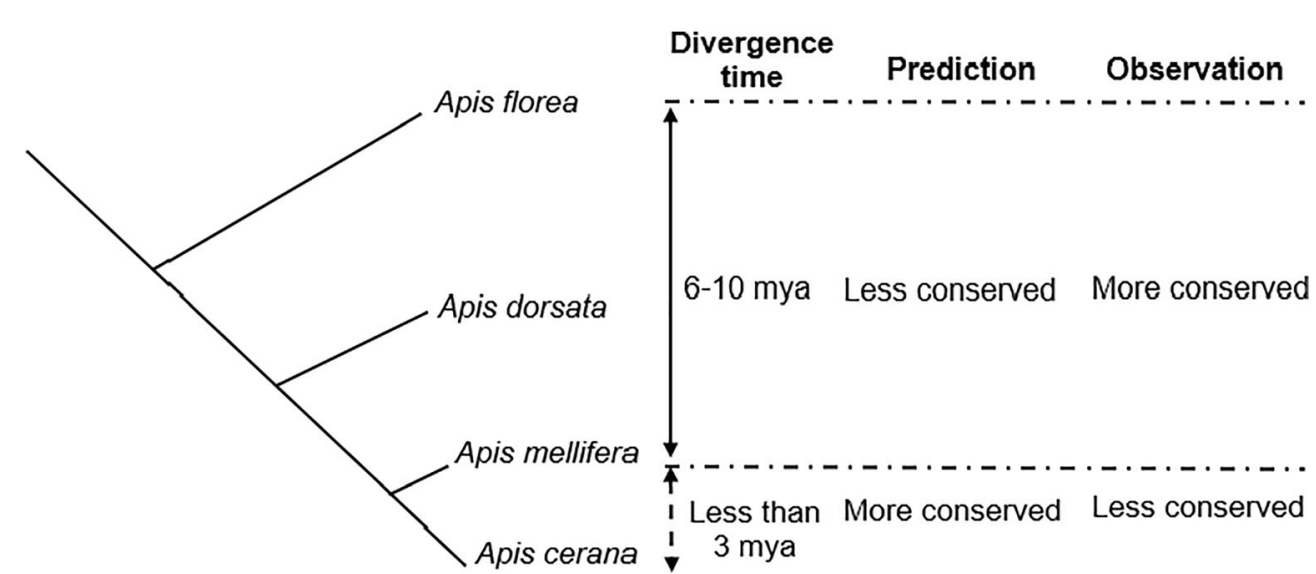

Figure 3. Phylogeny and divergence time of A florea, A . dorsata, A . mellifera, and A . cerana (modified from Oldroyd and Wongsiri 2006) with predicted and observed retention of the queen egg-marking signal based on the assumption that there has been an 'episode of revolution' in A cerana .

\section{ACKNOWLEDGEMENTS}

We thank Awirut Sopaladawan, Chutima Sa-nguanwattananon and Udomrit Srisarakorn for field work assistance. We thank Kittisak Farm for providing the place to perform the experiments. We further thank the reviewers for helpful comments and suggestions.

Contributions PNS and BPO designed the study. PNS performed the experiments and analyzed data. PNS and BPO wrote the paper. SW participated in revising the manuscript. All authors read and approved the final manuscript.

\section{FUNDING INFORMATION}

This work was financially supported by the Thailand Research Fund, the Office of the Higher Education Commission, and Mahasarakam University (grant number MRG5480052).

Les ouvrières d'Apis florea et d'Apis cerana ne font pas de distinction entre les oufs d'Apis mellifera pondus par la reine et ceux pondus par les ouvrières.

\section{Apis florea / Apis cerana / Apis mellifera / régulation} sociale / signaux de marquage des œufs

Arbeiterinnen von Apis florea und Apis cerana unterscheiden nicht zwischen Eiern, die von Apis mellifera-Königinnen oder -Arbeiterinnen gelegt wurden
Apis florea / Apis cerana / Apis mellifera / Arbeiterinnen Policing / Eimarkierende Signale

\section{REFERENCES}

Arias M.C., W.S. Sheppard. (2005) Phylogenetic relationships of honey bees (Hymenoptera:Apinae:Apini) inferred from nuclear and mitochondrial DNA sequence data. Mol Phylogenet Evol 37 (1): 25-35.

Barron A.B., B.P. Oldroyd, F.L.W. Ratnieks. (2001) Worker reproduction in honey-bees (Apis) and the anarchic syndrome: A review. Behav Ecol Sociobiol 50 : 199-208.

Beekman M., C.G. Martin, B.P. Oldroyd. (2004) Similar policing rates of eggs laid by virgin and mated honeybee queens. Naturwissenschaften 91 : 598-601.

Bourke A.F.G. (1988) Worker reproduction in the higher Eusocial Hymenoptera. Q Rev Biol 63 (3): 291-311.

Collett D. (1994) Modelling survival data in medical research. Chapman \& Hall, London.

Crozier R.H., P. Pamilo. (1996) Evolution of social insect colonies. Sex allocation and kin selection. Oxford University Press, Oxford.

Dzierzon J. (1845) Gutachten über die von Herrn Direktor Stöhr im ersten und zweiten Kapitel des GeneralGutachtens aufgestellten Fragen. Eichstädter Bienenzeitung 1 : 109-113, 119-121.

Engel M.S. (1998) Fossil honey bees and evolution in the genus Apis (Hymenoptera: Apidae). Apidologie 29: 265-281. 
Engel M.S. (1999) The taxonomy of recent and fossil honey bees (Hymenoptera: Apidae; Apis). J Hymenopt Res 8(2): 165-196.

Halling L.A., B.P. Oldroyd, W. Wattanachaiyingcharoen, A.B. Barron, P. Nanork, et al. (2001) Worker policing in the bee Apis florea. Behav Ecol Sociobiol 49 : 509513.

Hamilton W.D. (1964) The genetical evolution of social behaviour. I \& II. J Theor Biol 7 : 1-52.

Hefetz A., T. Katzav-Gozansky. (2004) Are multiple honeybee queen pheromones indicators for a queenworkers arms race? Apiacta 39: 44-52.

Heinz J., P. d'Ettorre. (2009) Honest and dishonest communication in social Hymenoptera. J Exp Biol 212 (1775-1779).

Holmes M.J., B.P. Oldroyd, M. Duncan, M.H. Allsopp, M. Beekman. (2013) Cheaters sometimes prosper: targeted worker reproduction in honeybee (Apis mellifera) colonies during swarming. Mol Ecol 22 (16): 4298-4306.

Jäger G. (2008) Evolutionary stability conditions for signaling games with costly signals. J Theor Biol 253 (1): 131-141.

Katzav-Gozansky T., V. Soroker, A. Hefetz. (1997) Plasticity of caste-specific Dufour's gland secretion in the honey bee (Apis mellifera L.). Naturwissenshaften 84 : $238-241$.

Katzav-Gozansky T., V. Soroker, F. Ibarra, W. Francke, A. Hefetz. (2001) Dufour's gland secretion of the queen honeybee (Apis mellifera): an egg discriminator pheromone or a queen signal? Behav Ecol Sociobiol 51 (1): 76-86.

Kuszewska K., A. Waclawaka, M. Woyciechowski. (2018) Reproduction of rebel workers in honeybee (Apis mellifera ) colonies. Apidologie 49(2): 162-171.

Lo N., R.S. Gloag, D.L. Anderson, B.P. Oldroyd. (2010) A molecular phylogeny of the genus Apis suggests that the giant honey bees of the Philippines, A . breviligula Maa and the plains honey bees of southern India, $A$. indica Fabricius are valid species. Syst Entomol 35: 226-238.

Martin S.J., G.R. Jones, N. Châline, H. Middleton, F.L.W. Ratnieks. (2002) Reassessing the role of the honeybee (Apis mellifera) Dufour's gland in egg marking. Naturwissenschaften 89: 528-532.

Martin S.J., N. Châline, F.L.W. Ratnieks, G.R. Jones. (2005) Searching for the egg-marking signal in honeybees. J Neg Res Ecol Evol 2 : 1-9.

Montague C.E., B.P. Oldroyd. (1998) The evolution of worker sterility in honey bees: an investigation into a behavioral mutant causing a failure of worker policing. Evolution 52 (5): 1408-1415.

Nanork P., J. Paar, N.C. Chapman, S. Wongsiri, B.P. Oldroyd. (2005) Asian honey bees parasitize the future dead. Nature 437 (6): 829.

Nanork P., S. Wongsiri, B.P. Oldroyd. (2006) The reproductive dilemmas of queenless red dwarf honey bee
(Apis florea ) workers. Behav Ecol Sociobiol 61 : 9197.

Nanork P., N.C. Chapman, S. Wongsiri, J. Lim, S. Gloag, et al. (2007a) Social parasitism by workers in queenless and queenright Apis cerana colonies. Mol Ecol 16 : 1107-1114.

Nanork P., S. Wongsiri, B.P. Oldroyd. (2007b) Preservation and loss of the honey bee (Apis) egg-marking signal across evolutionary time. Behav Ecol Sociobiol 61 : 1509-1514.

Nanork P., P.A. Low, K.M. Proft, J. Lim, S. Deowanish, et al. (2011) Actual reproductive conflict during emergency queen rearing in Apis florea. Apidologie 42 (2): 206-210.

Oldroyd B.P., K.E. Osborne. (1999) The evolution of worker sterility in honeybees: the genetic basis of failure of worker policing. Proc R Soc Lond B 266 (1426): 1335-1339.

Oldroyd B.P., F.L.W. Ratnieks. (2000) Evolution of worker sterility in honey-bees (Apis mellifera): how anarchistic workers evade policing by laying eggs that have low removal rates. Behav Ecol Sociobiol 47 : 268-273.

Oldroyd B.P., S. Wongsiri. (2006) Asian honey bees. Biology, conservation and human interactions. Harvard University Press, Cambridge

Oldroyd B.P., L.A. Halling, G. Good, W. Wattanachaiyingchareon, A.B. Barron, et al. (2001a) Worker policing and worker reproduction in Apis cerana. Behav Ecol Sociobiol 50 : 371-377.

Oldroyd B.P., T.C. Wossler, F.L.W. Ratnieks. (2001b) Regulation of ovary activation in worker honey-bees (Apis mellifera ): larval signal production and adult response thresholds differ between anarchistic and wild-type bees. Behav Ecol Sociobiol 50 : 366-377.

Oldroyd B.P., F.L.W. Ratnieks, T.C. Wossler. (2002) Egg marking pheromones in honey bees Apis mellifera. Behav Ecol Sociobiol 51 : 590-591.

Raffiudin R., R.H. Crozier. (2007) Phylogenetic analysis of honey bee behavioral evolution. Mol Phylogenet Evol 43 (2): 543-552.

Ratnieks F.L.W. (1988) Reproductive harmony via mutual policing by workers in eusocial Hymenoptera. Am Nat 132 : 217-236.

Ratnieks F.L.W. (1993) Egg-laying, egg-removal, and ovary development by workers in queenright honey bee colonies. Behav Ecol Sociobiol 32 : 191-198.

Ratnieks F.L.W. (1995) Evidence for queen-produced eggmarking pheromone and its use in worker policing in the honey bee. J Apic Res 34 (1): 31-37.

Ratnieks F.L.W., H.K. Reeve. (1992) Conflict in singlequeen Hymenopteran societies: the structure of conflict, and processes that reduce conflict in advanced eusocial species. J Theor Biol 158 : 33-65.

Ratnieks F.L.W., P.K. Visscher. (1989) Worker policing in honeybees. Nature 342 : 796-797.

Ratnieks F.L.W., T. Wenseleers. (2005) Policing insect societies. Science 307 : 54-56. 
Ratnieks F.L.W., K.R. Foster, T. Wenseleers. (2006) Conflict resolution in insect societies. Annu Rev Entomol 51: 581-608.

Seeley T.D. (1985) Honeybee ecology. Princeton University Press, Princeton.

Taber S. (1961) Forceps designed for transferring honey bee eggs. J Econ Entomol 54 : 247-250.

Visscher P.K. (1996) Reproductive conflict in honey bees: a stalemate of worker egg-laying and policing. Behav Ecol Sociobiol $39: 237-244$.

Wattanachaiyingcharoen W., B.P. Oldroyd, G. Good, L.A. Halling, F.L.W. Ratnieks, et al. (2002) Lack of worker reproduction in Apis dorsata. Insect Soc 49: 80-85.

Wenseleers T., F.L.W. Ratnieks. (2006) Enforced altruism in insect societies. Nature $444: 50$.
Wenseleers T., A.G. Hart, F.L.W. Ratnieks. (2004a) When resistance is useless: Policing and the evolution of reproductive acquiescence in insect societies. Am Nat 164 (6): E154-E167.

Wenseleers T., H. Helanterä, A. Hart, F.L.W. Ratnieks. (2004b) Worker reproduction and policing in insect societies: an ESS analysis. J Evol Biol 17 : 1035-1047.

Woyciechowski M., K. Kuszewska. (2012) Swarming generates rebel workers in honeybees. Curr Biol 22 : 707711.

Publisher's note Springer Nature remains neutral with regard to jurisdictional claims in published maps and institutional affiliations. 